\title{
Teacher education: is it beating its head on a brick wall?
}

Bruno Teles Nunes ${ }^{\mathrm{a}}$

\section{Abstract}

Brazilian basic education still lacks qualified teachers. The Brazilian Open University System (UAB) is a branch of a public educational policy designed to address that problem. This quantitative/descriptive paper analyses UAB System statistics (2006 to June 2015), specifically regarding vacancies, enrolment and the number of students that graduate. It was revealed that $68.3 \%$ of all vacancies were allocated to teacher education courses, and within that sphere $67.5 \%$ were degree courses for basic education teachers and $32.4 \%$, complementary courses. The enrolment percentage was around $86 \%$, while the proportion of students graduating was around $61 \%$. Analysis of the figures suggests that the UAB sought to achieve its main goal, as a public policy that induces teacher education for Brazilian basic education teaching staff. However, it is conjectured that problems related to the teaching profession itself discourage students from joining and from finalizing their courses, thereby weakening the potential performance of the UAB System.

Keywords: Education policy. Teacher education. Brazilian Open University System (UAB).

\section{Introduction: A Renewed Problem}

An increasing body of research reveals how unattractive the teaching profession is in Brazil largely due to low prestige, poor pay, the gap between qualification and reality, violence in schools and a multitude of other factors (BARRETTO, 2015; GATTI, 2014). Research has also questioned why high enrolment levels in teaching degree courses persist alongside a shortage of teachers in schools, especially for certain teaching subjects and in certain regions: could it be that there are "too few teachers and too many with teaching degrees?" (PALAZZO; GOMES, 2017). Two refrains have been historically reiterated: devaluation of educators and lack of them.

a Universidade Católica de Brasília, Brasília, DF, Brasil.

Recebido em 10 abr. 2017

Aprovado em 13 jun. 2017 
An intelligent decision was made in 2006 to stimulate the qualification of teachers for basic education by means of the Brazilian Open University System (UAB is the Portuguese acronym) under the administration of the Coordination for the Improvement of Higher Education Personnel (Coordenação de Aperfeiçoamento de Pessoal de Nivel Superior - Capes). The underlying logic is consistent: distance education is flexible, low cost compared to physical attendance courses, public and free of charge to the students, has a notorious capillarity, can reach out to distant places and allows for the use of high quality teaching materials and staff.

Has a program with such a broad outreach as the UAB effectively met those needs? Has the money (correctly) invested been transformed into tangible contributions? This paper sets out to delineate the answers to those questions by analyzing the data from UAB. It touches on an assessment that transcends that ambit, however, and it is worthwhile keeping up the suspense as to whether we are still producing too many graduates with teaching qualifications but not enough teachers. Even the best objectives and strategies and the richest arrays of talents can encounter serious obstacles when they are incarnated in reality or try to become.

\subsection{Justification}

According to the 2000 School Census data analyzed by Neder (2006), at the end of the last century, $48.8 \%$ of teachers working in Basic Education did not have a suitable higher education qualification with a strong concentration of them (42.8\%) in primary and lower secondary education; at the beginning of the present century the number of lay teachers in Brazil (those without initial or complementary teacher education suitable for their activities) was over 1.1 million.

Recent research has identified a reduction in the deficit of teachers duly qualified to work in basic education but the situation is still disquieting. According to Alves and Silva (2013) analyses of the 2009 School Census data show that $35.4 \%$ of teachers did not have a suitable qualification. The Census for 2016 shows a deficit of $22.5 \%$ for a total of 2.19 million teaching posts (INEP, 2017).

The problem continues to be on the government agenda, so much so that the most recent National Education Plan 2014 - 2024, when setting out a macro-script for action in the educational context on the theme of "adequate education for basic education teachers", dedicates two goals, 15 and 16 respectively, to initial teacher education and continuing teacher education.

The qualification problem may be boosted by questions associated to the teaching career itself. Peixoto $(2012$, p. 88) notes that there is a lack of interest in teaching 
careers, especially those associated to a teaching degree due to the "low value of the respective diploma in the economic goods and symbolic goods markets". When people actively select teaching, they do so because of aspects that are intrinsic to the career, such as personal gratification in being a teacher; on the other hand, they reject the career for extrinsic reasons, such as the low social value that is attributed to it (PALAZZO; GOMES, 2017). Teaching careers are not supported by adequate career plans that contemplate professional ascension, or by decent salaries or other benefits such as health plans (BARRETTO, 2015; GATTI, 2014).

The socioeconomic profiles of people that enroll in teaching degree courses amplifies the problem of teacher education. According to Gatti (2014) the profile of the student body consists of individuals: a) from low-income families, 39\% with household incomes of up to 3 minimum salaries and $51 \%$ with from 3 to 10 ; b) $98 \%$, not only study but work as well; c) their parents have low schooling levels, and d) $54 \%$ are outside the ideal age group for teacher education (18 to 24 ).

Students with the above profile have entered the course for economic or employability reasons. Courses in the field of education are less expensive for the student and the mere fact of obtaining a higher education diploma can guarantee them employment in activities other than teaching ('credentialism') or the teaching activity may be practiced merely to bring in a little additional income, a kind of side line (PALAZZO; GOMES, 2017).

Finally, teachers are needed, not only to increase the body of persons in teaching and teaching-related activities but also to fill the posts that will become vacant in the coming years. According to the Basic Education Census of 2016, 49.4\% of teaching positions are occupied by people over 40 years old and that fact is exacerbated by the predominant participation of women $(82 \%)$, given that women have the right to an earlier retirement from their teaching activities.

\section{Brazil's Open University System (UAB)}

Gomes (2009) reports that distance education in the higher education level in Brazil first materialized in 1995 with the creation of the Special Department for Distance Education. The Law of Bases and Directives $n^{\circ}$ 9.394/1996 (specifically article 80 ), finally endowed it with new status as it was formerly an exception or operated clandestinely (BRASIL, 1996). Furthermore, Almeida and Costa (2009) affirm that the Law unleashed a chain of recognition for distance education in Brazil and accordingly it came to require the definition of public policies for its implementation and consolidation. Additionally, Neder (2006), asserts that the focus of distance education should not be restricted merely to democratizing 
access to higher education but should embrace teacher education as well, making full use of that modality's potential.

In its National Education Plan 2001-2011 (Law 10.172/2001) and more specifically in Chapter 6 - Distance Education and Educational Technologies, the Brazilian State, pressured by the need to elaborate public policies to solve the qualification problem, underscored the importance of distance education as a priority means for achieving the continuing education of teachers working in primary and lower secondary education (BRAZIL, 2001).

Furthermore, in 2005, in the Ministry of Education (MEC), the Open University System began to be idealized. The Decree $\mathrm{n}^{\circ} 5.800 / 2006$, which legitimized the UAB System, declares that it should set priority on initial and continuing education for basic education teachers (BRAZIL, 2006).

Since 2008, the UAB has been the responsibility of Capes and specifically, of the Distance Education Directorate (DED). The operational foundation of the UAB rests on a cooperation between Capes, participating public universities, States and Municipalities. These last two are responsible for maintaining locations of attendance in the form of spaces in buildings and administrative support personnel.

The DED is responsible for the macro-management of UAB: 1) approving the participation of the centers supporting student attendance and monitoring their infrastructure and the way they function; 2) monitoring the demand in the states for teacher education, making the course offer feasible and accompanying it; 3) making the financing of the universities feasible and accompanying the execution of the allocated resources. The role of the public universities is to propose the course offers, administer the student selection process, promote the academic activities of the courses, and manage the execution of the financial resources.

The data were obtained from the UAB System in July 2015 concerning the courses offered by the participating institutions in the period from February 2006 to June 2015. The data regarding the date courses began are merely declaratory and inserted into the computational tool used to manage the UAB by the educational institutions themselves and, up until then, there had been no way of validating them.

\section{Results}

From 2006 to June 2015 the UAB aggregated 853 courses to 14,171 classes, and made available 607,675 places (Table 1). It reveals two interesting results: 1) in the division 
Table 1. Total numbers of courses, classes and places found in the UAB.

\begin{tabular}{lcccccc}
\hline \multirow{2}{*}{ Type of course } & \multicolumn{2}{c}{ A - Courses } & \multicolumn{2}{c}{ B - Classes } & \multicolumn{2}{c}{ C - Places } \\
\cline { 2 - 7 } & $\mathbf{N}$ & $\%$ & $\mathbf{N}$ & $\%$ & $\mathbf{N}$ & $\%$ \\
\hline Other qualifications & 274 & 32.1 & 4,202 & 29.6 & 192,075 & 31.6 \\
$\quad$ Degree & 85 & 31.0 & 1,721 & 40.9 & 79,868 & 41.5 \\
$\quad$ Complementary & 189 & 68.9 & 2,481 & 59.0 & 112,207 & 58.4 \\
Teacher education & 579 & 67.9 & 9,969 & 70.4 & 415,6 & 68.4 \\
$\quad$ Degree & 328 & 56.6 & 6,495 & 65.1 & 280,723 & 67.5 \\
$\quad$ Complementary & 251 & 43.3 & 3,474 & 34.8 & 134,877 & 32.4 \\
Total & 853 & 100.0 & 14,171 & 100.0 & 607,675 & 100.0 \\
\hline
\end{tabular}

Source: Elaborated by the author based on UAB data (2016).

in three columns, the percentages associated to teacher education are considerably higher than those associated to "Other Qualifications": A - 67.8\%, B - 70.3\% e $\mathrm{C}-68.3 \%$, in relation, respectively, to A $-32.1 \%$, B $-29.6 \%$, e C $-31.6 \%$; in the group "Other Qualifications", for every degree course there are 2.2 complementary ones and in the case of classes and places the ratio is 1.4. A comparison of those numbers with the numbers associated to the group "Teacher Education" shows a diametrical behavior. In this case for each complementary course there that ratio is 1.3 degree courses and for the classes and places the numbers are 1.8 and 2, respectively.

Comparisons among different kinds of qualification show that for each bachelor/technological course there were 3.8 times more teaching degree courses and the numbers for classes and places are 3.7 and 3.5, respectively. Applying the same treatment to the Complementary courses, we found less expressive numbers but they ratify the inducement to more teacher education: 1.3 times more courses, 1.4 times more classes and 1.2 times more places.

Table 2 has been designed to permit a horizontal comparison of the numbers set out in Table 1, to present the aggregate figures for the number of classes for each course and the same logic for classes and places.

Based on the totals (highly aggregated numbers), each UAB course contemplated 16.6 classes with 42.8 students per class. These numbers grouped according to type of qualification and purpose, are very similar. Thus, we can conjecture as to whether the UAB System's complementary and degree courses, irrespective of whether they are directed at teacher education or not, support similar numbers of classes and student places and whether their potentials are equivalent. 
Table 2. Ratios of numbers of courses, classes and places.

\begin{tabular}{lcc}
\hline \multirow{2}{*}{ Type of course } & $\mathbf{B / A}$ & $\mathbf{C / B}$ \\
\cline { 2 - 3 } & $\mathbf{N}$ & $\mathbf{N}$ \\
\hline Other qualifications & 15.3 & 45.7 \\
Degree & 20.2 & 46.4 \\
Complementary & 13.1 & 45.2 \\
Teacher education & 17.2 & 41.6 \\
Degree & 19.8 & 43.2 \\
Complementary & 13.8 & 38.8 \\
Total & 16.6 & 42.8 \\
\hline
\end{tabular}

A: courses; B: classes; C: places.

Source: Elaborated by the author based on UAB data (2016).

The comparisons commented in the preceding paragraphs have revealed two inducement tendencies. The UAB has functioned in educating new teachers and, albeit residually, in qualifying teachers already in activity in new areas of knowledge; in the aspect of other qualifications it focused on aggregating complementary knowledge. In other words, the UAB has sought to induce the education of teachers thereby fulfilling its primordial objective.

Considering these observations, can the percentage relations in Table 1 be considered ideal? Could they be improved? Supposing that the courses have similar qualifying potential, if the UAB were to redirect the institutional efforts, it would dedicate to Other Qualifications to teacher education instead, could the achievement of the primordial objective be expanded? We do not have the answers for now, but such questions suggest further studies.

Scrutiny of the data showed that only 3 courses were registered as having been cancelled. Apart from the numbers being statistically insignificant, the current inactivity of those courses does not mean they were not active at some time or another. Oppositely, 1,588 classes $(11.2 \%$ of the total) were cancelled or never actually started. The failure to start off the activities of a class in any given attendance support center triggers effects on the number of places whose reduction implies there will also be reductions in enrolment and undergraduate figures.

Table 3 presents a different level of des-aggregation according to the number of places available or occupied, by regions where the classes were organized. 
Table 3. Patterns of the UAB place offer by regions.

\begin{tabular}{lccccc}
\hline \multirow{2}{*}{ Region/Type of course } & \multicolumn{2}{c}{ A - Places offered } & B - Places cancelled* & B/A \\
\cline { 2 - 5 } & $\mathbf{N}$ & $\%$ & $\mathbf{N}$ & $\%$ & $\%$ \\
\hline North & 24,803 & 5.9 & 4,625 & 11.1 & 18.6 \\
Degree & 17,881 & 72.0 & 2,175 & 47.0 & 12.1 \\
Complementary & 6,922 & 27.9 & 2,45 & 52.9 & 35.3 \\
Northeast & 140,18 & 33.7 & 12,278 & 29.4 & 8.7 \\
Degree & 113,613 & 81.0 & 6,798 & 55.3 & 5.9 \\
Complementary & 26,567 & 18.9 & 5,48 & 44.6 & 20.6 \\
Southeast & 146,277 & 35.2 & 14,571 & 34.9 & 9.9 \\
Degree & 81,595 & 55.7 & 6,252 & 42.9 & 7.6 \\
Complementary & 64,682 & 44.2 & 8,319 & 57.0 & 12.8 \\
South & 78,488 & 18.9 & 5,9 & 14.1 & 7.5 \\
Degree & 49,826 & 63.4 & 2,7 & 45.7 & 5.4 \\
Complementary & 28,662 & 36.5 & 3,2 & 54.2 & 11.1 \\
Central-West & 25,852 & 6.2 & 4,34 & 10.4 & 16.7 \\
Degree & 17,808 & 68.8 & 2,64 & 60.8 & 14.8 \\
Complementary & 8,044 & 31.1 & 1,7 & 39.1 & 21.1 \\
Total & 415,6 & 100.0 & 41,714 & 100.0 & 10.0 \\
\hline Cancelled/no-started & & & & &
\end{tabular}

${ }^{*}$ Cancelled/no-started classes.

Source: Elaborated by the author based on UAB data (2016).

A vertical analysis of column A shows that the installed capacity of the place offer is consistent with what has already been observed, namely, that the system has favored teaching degrees to the detriment of complementary courses. In the Southeast macro region, the numbers are closer to one another which may indicate that the demand for new teachers is lower than in other regions. In macro regions North and Northeast, however, the place offer for teaching degree courses is expressive, which suggests a possibly serious shortage of new teachers. Although we cannot distinctly affirm causality, these last two regions present the lowest mean values (according to recent surveys) for the Basic Education Development Index (Índice de Desenvolvimento da Educação - IDEB). Northeast and Southeast account for $69.5 \%$ and $67.6 \%$ of the places, respectively (total of degree courses and complementary courses). Those figures are influenced by the numbers of universities located in the two regions. Together they account for $63 \%$ of the total number of institutions participating in the UAB. 
On analyzing the composition of the total number of places $(47,714)$ in cancelled or no started classes shown in column B, we can conclude that the numbers for degree courses $(49.3 \%)$ and complementary courses (50.7\%) are similar. In the light of that vertical analysis Northeast (29.4\%) and Southeast (34.9\%) contributed substantially to the composition of the total, albeit the profiles of their cancelled classes were different. Former cancelling refers predominantly complementary courses, whereas the later degree course classes were cancelled more than the others. The two regions' high figures for this item are due to the fact that they offered much higher numbers of places in the first place. It should be mentioned that in the Central-Western region, most cancelled classes were of degree courses.

A complementary horizontal analysis of the same Table 3 - column B/A shows that, in principle, $10 \%$ of the places were lost. All regions cancelled places in complementary courses proportionally, 2.3 times more on average. North and Central-West presented the highest percentages of places not implemented, 18.6\% and $16.7 \%$, respectively. That fact differs from the conclusions of the horizontal analyses. In other words, those regions, with the lowest offer, were the ones that made least efficient use of their potential occupation. They did not even get to the point of setting in motion the selection process to occupy them.

It is not exactly a case of supply and demand: the classes/places that were cancelled or not started never had a chance of being occupied. Accordingly, certain questions arise from the information in Table 3 . A loss of up to $10 \%$ might be an acceptable figure, but, in fact, it represents 20,565 potential new teachers that will never come to be and 21,149 others that could have had their knowledge enhanced, but did not. Why were those classes/places cancelled or why did they fail to start? Were the quantities involved not properly dimensioned beforehand? Did the actors and processes involved fail to perform as expected? Was there any lack of resources that made it impossible to start the classes?

One of the variables for establishing funds for a new class was the number of available places, in 2006-14. Considering the context portrayed above we can conjecture that there was a considerable volume of financial resources that went unused.

Table 4 portrays the occupation of places effectively occupied in the selection process from 2006 to June 2015.

Of the 373,886 implemented places, 321,575 (86\%) were actually taken up. With exception of North and Northeast, whose rates of occupation in the complementary courses were $64 \%$ and $72.5 \%$ respectively, the rates were satisfactory which 
Table 4. Relationship between place offers and enrolments, by regions and by type of course.

\begin{tabular}{lccc}
\hline \multirow{2}{*}{ Region/Type of course } & A - Place offer & B - Enrolment & B/A \\
\cline { 2 - 4 } North & $\mathbf{N}$ & $\mathbf{N}$ & $\%$ \\
Complementary & 20,178 & 16,192 & 80.2 \\
Degree & 4,472 & 2,862 & 64.0 \\
Northeast & 15,706 & 13,33 & 84.8 \\
Complementary & 127,902 & 107,548 & 84.0 \\
Degree & 21,087 & 15,305 & 72.5 \\
Southeast & 106,815 & 92,243 & 86.3 \\
Complementary & 131,706 & 113,937 & 86.5 \\
Degree & 56,363 & 48,547 & 86.1 \\
South & 75,343 & 65,39 & 86.7 \\
Complementary & 72,588 & 65,665 & 90.4 \\
Degree & 25,462 & 23,653 & 92.9 \\
Central-West & 47,126 & 42,012 & 89.1 \\
Complementary & 21,512 & 18,233 & 84.7 \\
Degree & 6,344 & 5,707 & 89.9 \\
Total & 15,168 & 12,526 & 82.5 \\
\hline & 373,886 & 321,575 & 86.0 \\
\hline
\end{tabular}

Source: Elaborated by the author based on UAB data (2016).

may indicate that those two regions had a greater need of new teachers. It is worth noting that macro region North failed to implement $35.3 \%$ of the places in complementary courses, which means that $58.5 \%$ of the planned places were lost. Macro region South heads the list with the best percentages taken up, $90.46 \%$.

The ideal of $100.0 \%$ occupation may be hard to achieve but it should be aimed at. None of the percentages detected was above $95 \%$ and the mean percentage of places effectively occupied was $83.5 \%$. In that light, we propose the following conjectures: was the level of occupation less than excellent because of the lack of demand, in other words because there was less than one candidate per place? Or, did the selection processes approve a sufficient number of candidates but some of the latter decided not to matriculate? The idea of those speculations is to evoke the phantom of the lack of attractiveness of the teaching career indicated by the studies that have been cited in the text above (BARRETTO, 2015; GATTI, 2014; PALAZZO, GOMES, 2017; PEIXOTO, 2012). 
In an endeavor to make a more in-depth analysis of places' occupation of the places offered, the figures in Table 4 have been des-aggregated by areas of knowledge and qualification to which the respective courses were associated using the Organisation for Economic Co-operation and Development (OECD) classification adopted by the UAB, and they are presented accordingly in Table 5. For a best reading, we aggregated the areas in categories, Courses Areas (CA):
a) CA-1 - Agriculture and Veterinary Science;
b) CA-2 - Social Sciences, Business and Law;
c) CA-3 - Sciences, Mathematics and Computing;
d) CA-4 - Education;
e) CA-5 - Humanities and Arts;
f) CA-6 - Health and Social Wellbeing;
g) CA-7 - Services.

Vertical analysis of the Complementary Courses column reveals large allocation to Education, which accounted for $72.7 \%$ of the total number of places. The same is true for most of the regions with the lowest percentage being for the Northeast, 59\%. Notably, the South and Central-Western regions respectively offered 2 and 1.3 times more complementary courses available than teaching degree courses. Thus, we can suppose, about complementary qualification, that the UAB channeled its efforts to offering opportunities for educators and professionals with other qualifications to acquire and improve their knowledge in the education field.

Vertical analysis of the Degree Courses column, however, finds that a considerably different panorama. A considerable portion of the places is distributed among three areas: Sciences, Mathematics and Computing (108,799 - 41.8\%); Education (75,291 - 28.9\%) and Humanities and Arts (66,402-25.5\%). Except for the South where there seems to be a greater demand for professionals qualified in education, the others reveal a demand for teachers in the areas of Sciences, Mathematics and Computing. In spite of being in third place in the distribution of places, the area of Humanities and Arts is the second in the ranking by region, except for Southeast, in the second place in courses on Education. 
Table 5. Relationship between quantity of places and effective enrolment, by course areas.

\begin{tabular}{|c|c|c|c|c|c|c|}
\hline \multirow{2}{*}{ Region/Couse area } & \multicolumn{2}{|c|}{$\begin{array}{c}\text { A - Complementary } \\
\text { courses }\end{array}$} & \multicolumn{2}{|c|}{ B - Degree courses } & \multicolumn{2}{|c|}{ \% Places occupied } \\
\hline & Places & Enrolled & Places & Enrolled & A & B \\
\hline North & 4,472 & 2,862 & 15,706 & 13,33 & 64.0 & 84.8 \\
\hline$C A-1$ & - & - & 590 & 599 & - & 101.5 \\
\hline $\mathrm{CA}-3$ & 190 & 53 & 6,732 & 5,318 & 27.8 & 79.0 \\
\hline$C A-4$ & 3,546 & 2,521 & 3,693 & 3,386 & 71.0 & 91.6 \\
\hline$C A-5$ & 130 & 163 & 3,833 & 3,127 & 125.3 & 81.5 \\
\hline CA-6 & 606 & 125 & 858 & 900 & 20.6 & 104.9 \\
\hline Northeast & 21,087 & 15,305 & 106,815 & 92,243 & 72.5 & 86.3 \\
\hline$C A-1$ & - & - & 1,96 & 1,918 & - & 97.8 \\
\hline CA-2 & 1,17 & 629 & 260 & 159 & 53.7 & 61.1 \\
\hline CA-3 & 3,87 & 2,834 & 47,525 & 39,809 & 73.2 & 83.7 \\
\hline $\mathrm{CA}-4$ & 12,454 & 8,989 & 18,715 & 17,256 & 72.1 & 92.2 \\
\hline$C A-5$ & 2,33 & 1,936 & 36,958 & 31,737 & 83.0 & 85.8 \\
\hline CA-6 & 1,263 & 917 & 1,397 & 1,364 & 72.6 & 97.6 \\
\hline Southeast & 56,363 & 48,547 & 75,343 & 65,39 & 86.1 & 86.7 \\
\hline CA-2 & 330 & 231 & 350 & 311 & 70.0 & 88.8 \\
\hline$C A-3$ & 9,974 & 6,008 & 39,677 & 33,097 & 60.2 & 83.4 \\
\hline CA-4 & 42,743 & 39,941 & 21,347 & 20,089 & 93.4 & 94.1 \\
\hline CA-5 & 2,176 & 1,711 & 11,41 & 9,815 & 78.6 & 86.0 \\
\hline CA- 6 & 1,14 & 656 & 867 & 592 & 57.5 & 68.2 \\
\hline CA-7 & - & - & 1,692 & 1,486 & - & 87.8 \\
\hline South & 25,462 & 23,653 & 47,126 & 42,012 & 92.9 & 89.1 \\
\hline CA-2 & 1,403 & 1,517 & 400 & 400 & 108.1 & 100 \\
\hline$C A-3$ & 3,005 & 2,499 & 8,15 & 6,661 & 83.1 & 81.7 \\
\hline CA-4 & 19,229 & 18,576 & 27,991 & 25,884 & 96.6 & 92.4 \\
\hline CA-5 & 860 & 574 & 10,005 & 8,514 & 66.7 & 85.1 \\
\hline CA-6 & 965 & 487 & 580 & 553 & 50.4 & 95.3 \\
\hline Central-West & 6,344 & 5,707 & 15,168 & 12,526 & 89.9 & 82.5 \\
\hline CA-3 & 1,159 & 980 & 6,715 & 5,388 & 84.5 & 80.2 \\
\hline CA-4 & 4,705 & 4,298 & 3,545 & 3,204 & 91.3 & 90.3 \\
\hline CA-5 & 420 & 403 & 4,196 & 3,292 & 95.9 & 78.4 \\
\hline CA- 6 & 60 & 26 & 712 & 642 & 43.3 & 90.1 \\
\hline Totals & 113.728 & 96.074 & 260.158 & 225.501 & 84.4 & 86.6 \\
\hline
\end{tabular}

Source: Elaborated by the author based on UAB data (2016). 
The column headed "Percentage of Places Occupied" allows to see the occupation rates. Figures above $100.0 \%$ result from some courses managed to enroll more students than the number of places originally made available. These are residual cases that call for more detailed studies.

When we analyze the rate of occupation of places in the complementary courses, we find that regions Southeast, South and Central-West have high rates, around an average of $93.7 \%$. For the regions North and Northeast, however, the mean rate of occupation is just $71.6 \%$. This means that almost $30 \%$ of the initial effort was dissipated before the classes even began and that was unfortunately in the two regions with the lowest average IDEB ratings.

Focusing on the degree courses, only two regions registered occupation rates could be considered merely regular (below 70\%), namely, the Northeast in the area of Social Sciences, Business and Law with $61.1 \%$ and the Southeast in the area of Health and Social Wellbeing with $68.2 \%$. To gain an understanding of the disparities in the place occupation figures the data need to be des-aggregated even further because sporadic facts in isolated institutions or courses may very well affect the overall figures. The other rates were close to a high average figure of $89.5 \%$, especially in the three regions that make the greatest numbers of places available, as has been shown.

Furthermore, the analysis of enrollments shows that $30.9 \%$ of them were in the Pedagogy courses. That percentage may represent progress in the number of enrollments in public courses in Pedagogy in the distance education mode identified by Barretto (2015) based on the 2011 Higher Education Census, whereby they represented $12.2 \%$ of all the teaching degree courses being offered by that means.

In general, places in the teaching degree classes are occupied satisfactorily despite the initial loss at the moment of implementation of the places of a potential $10 \%$ of those that could have eventually become qualified. For an appreciation of the broader scenario, the data collected after the implementation of the places must be analyzed to verify the numbers after the classes have concluded their course and find out how much of the original potential qualification is eventually fulfilled at the end of all the stages of this public policy.

Next tables display the absolute numbers referring to enrolment and graduation, des-aggregated by complementary and degree courses, and display the ratio between enrolment and graduation figures, revealing how much of their original qualification potential was actually fulfilled. To ensure that the comparison reflects 
the reality as closely as possible, the figures were based on those for classes declared as having concluded the course, so the number of matriculations in this case differs from those in the previous tables.

Table 6 shows that the UAB qualified 49,688 (51\%) new teachers and complemented the qualifications of an additional 47,665 (48.9\%) professionals. Those are considerable amounts, but as the courses unfolded a considerable number dropped out. $70.4 \%$ of those enrolled in complementary courses finished them, but in teaching degree courses only $55.1 \%$ completed all the academic activities. Thus, almost half of the effort to educate new teachers was dissipated during the process. Here again there is a convergence with the results reported by Palazzo and Gomes (2017) regarding the efficient use made of the teaching

Table 6. Ratios between numbers enrolled and numbers graduated by regions and by type of course based on concluded classes.

\begin{tabular}{lccc}
\hline Region/Type of course & A - Enrolled & B - Graduated & B/A \\
\cline { 2 - 4 } & $\mathbf{N}$ & $\mathbf{N}$ & $\%$ \\
\hline North & 8,123 & 5,669 & 69.7 \\
Complementary & 1,87 & 1,599 & 85.5 \\
Degree & 6,253 & 4,07 & 65.0 \\
Northeast & 43,139 & 25,862 & 59.9 \\
Complementary & 8,46 & 6,739 & 79.6 \\
Degree & 34,679 & 19,123 & 55.1 \\
Southeast & 57,644 & 35,356 & 61.3 \\
Complementary & 36,071 & 26,016 & 72.1 \\
Degree & 21,573 & 9,34 & 43.2 \\
South & 39,888 & 25,679 & 64.3 \\
Complementary & 17,449 & 10,893 & 62.4 \\
Degree & 22,439 & 14,786 & 65.8 \\
Central-West & 8,935 & 4,787 & 53.5 \\
Complementary & 3,807 & 2,418 & 63.5 \\
Degree & 5,128 & 2,369 & 46.2 \\
Complementary & 67,657 & 47,665 & 70.5 \\
Degree & 90,072 & 49,668 & 55.2 \\
Totals & 157,729 & 97,353 & 61.7 \\
\hline Source: & & &
\end{tabular}

Source: Elaborated by the author based on UAB data (2016). 
degree opportunities: students tend to leave their courses not between selection and enrollment, but during the course itself, which is the opposite of the situation of traditional teaching degree courses where the student attends all classes in person. Table 7 des-aggregates the data by areas of knowledge.

The analysis by area of qualification does not present a more encouraging scenario The course conclusion rates are modest and most negative among them are those for Sciences Mathematics and Computing where the mean percentage was $57.6 \%$ but for region North it was only $25 \%$. The area of education shows a regular result of $72.1 \%$ and the highest absolute number of qualified graduates, $40,098(84.1 \%)$. The Northeast also showed a regular result for graduation rate with none of the areas being lower than $70 \%$.

In regard to the teaching degree courses, the results discriminated by areas of knowledge repeat the pattern for the other courses. The areas of Sciences, Mathematics and Computing returned the lowest rate with an overall result of just $35.9 \%$ of enrolled students actually concluding their course. Other low percentages were for the Southeast (27.1\%) and South (29.3\%). The overall rate for the area of Education was higher, $73.1 \%$, with an outstanding $78 \%$ obtained by regions Northeast and South. On the whole the area of Humanities and Arts showed fair results with an average rate of graduation of $54.2 \%$.

The numbers displayed above reveal the existence of a serious problem. UAB System, especially in the teaching degree courses, has not managed to keep the enrolled students from dropping out of their classes as almost half of them fail to finalize their courses and there is an orverriding physics, chemistry, biology computing and geography teachers. The total enrollment numbers for Sciences, Mathematics and Computing, on the one hand, and Eduction on the other are similar 35,188 (39.8\%) and 33,219 (36.8\%), but their course conclusion rates are very different. In other words, the system is potentially educating and further qualifying students in Education more than any other area.

Assuming that the students that conclude their courses go on to work as teachers, the System is basically addressing the needs of infant education and the early years of fundamental education (primary). The later years of fundamental education (lower secondary) and higher secondary education are apparently jeopardised by that pattern. What are the factors that make it so difficult to educate teachers for what are considered the 'hard' study disciplines? Is the problem associated to Distance Education as a modality? Are we doomed to continue having educators that teach in areas that they did not originally qualify for? Given the falling birthrate figures, are we going to need so many people qualified in Education (IBGE, 2013)? 
Table 7. Relation between enrollment figures and course conclusion in courses declared as concluded.

\begin{tabular}{|c|c|c|c|c|c|c|}
\hline \multirow{2}{*}{ Region/Course areas } & \multicolumn{2}{|c|}{$\begin{array}{c}\text { A - Complementary } \\
\text { courses }\end{array}$} & \multicolumn{2}{|c|}{$\begin{array}{l}\text { B - Degree } \\
\text { courses }\end{array}$} & \multicolumn{2}{|c|}{ \% Conclusion } \\
\hline & Enrolled & Graduated & Enrolled & Graduated & A & B \\
\hline North & 1,87 & 1,599 & 6,253 & 4,07 & 85.5 & 65.0 \\
\hline$C A-1$ & - & - & 200 & 52 & - & 26.0 \\
\hline $\mathrm{CA}-3$ & 8 & 2 & 2,116 & 1,468 & 25.0 & 69.3 \\
\hline CA-4 & 1,737 & 1,48 & 2,045 & 1,493 & 85.2 & 73 \\
\hline$C A-5$ & - & - & 1,287 & 853 & - & 66.2 \\
\hline CA-6 & 125 & 117 & 605 & 204 & 93.6 & 33.7 \\
\hline Northeast & 8,46 & 6,739 & 34,679 & 19,123 & 79.6 & 55.1 \\
\hline CA-1 & - & - & 653 & 303 & - & 46.4 \\
\hline CA-3 & 1,066 & 839 & 16,903 & 7,699 & 78.7 & 45.5 \\
\hline $\mathrm{CA}-4$ & 5,99 & 4,777 & 7,153 & 5,586 & 79.7 & 78.0 \\
\hline CA-5 & 693 & 597 & 9,562 & 5,26 & 86.1 & 55.0 \\
\hline CA-6 & 711 & 526 & 408 & 275 & 73.9 & 67.4 \\
\hline Southeast & 36,071 & 26,016 & 21,573 & 9,34 & 72.1 & 43.2 \\
\hline CA-2 & - & - & 155 & 146 & - & 94.1 \\
\hline CA-3 & 4,221 & 2,349 & 11,28 & 3,061 & 55.6 & 27.1 \\
\hline$C A-4$ & 30,025 & 22,405 & 6,998 & 4,306 & 74.6 & 61.5 \\
\hline$C A-5$ & 1,169 & 641 & 2,46 & 1,483 & 54.8 & 60.2 \\
\hline CA-6 & 656 & 621 & 206 & 121 & 94.6 & 58.7 \\
\hline CA-7 & & & 474 & 223 & & 47.0 \\
\hline South & 17,449 & 10,893 & 22,439 & 14,786 & 62.4 & 65.8 \\
\hline$C A-2$ & 809 & 552 & 205 & 77 & 68.2 & 37.5 \\
\hline CA-3 & 1,667 & 885 & 3 & 879 & 53.0 & 29.3 \\
\hline CA-4 & 14,584 & 9,297 & 15,71 & 12,258 & 63.7 & 78.0 \\
\hline$C A-5$ & - & - & 3,38 & 1,477 & - & 43.7 \\
\hline CA- 6 & 389 & 159 & 144 & 95 & 40.8 & 65.9 \\
\hline Central-West & 3,807 & 2,418 & 5,128 & 2,369 & 63.5 & 46.2 \\
\hline$C A-3$ & 541 & 253 & 1,889 & 819 & 46.7 & 43.3 \\
\hline$C A-4$ & 3,24 & 2,139 & 1,313 & 659 & 66.0 & 50.1 \\
\hline$C A-5$ & - & - & 1,55 & 709 & - & 45.7 \\
\hline CA-6 & 26 & 26 & 376 & 182 & 100.0 & 48.4 \\
\hline Totals & 67,657 & 47,665 & 90,072 & 49,688 & 70.4 & 55.1 \\
\hline
\end{tabular}

Source: Elaborated by the author based on UAB data (2016). 
On the other hand, there are serious implications for the financial aspect. Lira and Lima (2014) report that in the period 2006 to 2013 the UAB received budget allocations to the tune of 2.46 billion reals. Reports published by the Coordinating Body for Supervision and Promotion (Coordenação de Supervisão $e$ Fomento - CGFO) of Capes show that the amount made available to the UAB in 2014 was 394.67 million reals (Brazilian currency). Adding that to the amount cited by Lira and Lima (2014), we obtain the figure of 2.86 billion reals. Two aspects of those figures need to be made clear: they are nominal figures that have not been subjected to any kind of correction or adjustment, and they are based on budget data which may be different to the amounts that were effectively used.

In the light of all those financial figures and the data displayed in Table 1 we can derive certain inferences, however primary they may be. We know that at least $60 \%$ of the UAB System's effort was directed at the initial and continuing education of teachers, given that 1.71 billion reals were allocated for that purpose. If we divide that figure by the number of course places actually implemented (Table 4), we obtain the value of a single implemented course place of 4.58 thousand reals. In those classes declared as concluded, 176,980 places were made available. We also know that the number that graduated was 97,353 (Table 6) thus 79,279 places were wasted either because the student decided not to enroll or because he or she did not conclude the course. That means we identify a possible resource waste around 363.10 million reals or USD 201.7 million (OECD, 2017). If figures were available for unfinished classes, the total amount could be considerably greater.

Thus it can be estimated that a large part of the UAB System's effort to induce teacher education goes to waste during the educational process. Obviously a $100 \%$ return on the investment is unlikely, but if $80 \%$ of the actual enrollments (Table 4) were fully taken advantage of (with students graduating at the end of their courses) then by the end of 2015 we could have 180,401 new teachers available for various teaching roles and another 76,859 having acquired a set of complementary knowledge. If, as the 2016 Basic Education Census indicates, $22.5 \%(494,107)$ of those in educational functions lack a proper qualification, the $\mathrm{UAB}$ would be able to reduce the problem by half in a few years. That estimate may be limited but it is designed to underscore the potential of the UAB.

\section{Final Conclusion}

The program analyzed revealed a low level of efficiency and efficacy, partially having achieved its objectives. Each unoccupied place, each enrolled student that failed to conclude the course represents a waste of resources. Even though the cost per student tends to be lower in distance education than in education with 
integral attendance, the amount is highly significant in a program with national outreach. New questions that arise are: do the qualified educators actually work? If so, do they work in areas that need them most? Does their education and training result in learning on the part of the students they teach?

Those are profound questions but for some time now, international experiences have shown that distance education needs to address complex internal and external conditions associated to the students' realities. While the cost tends to be lower, drop out rates tend to be high so the latter annuls the effect of the former (GOMES, 1994). That was an aspect that Darcy Ribeiro ordered to be investigated before proposing the Law that bears his name and set distance education in motion in Brazil. Outstanding among the usual remedies applied and improved on, are acquiring good knowledge of the real and potential students, accompanying them constantly requiring their actual presence or presence at a distance in the so-called "learning communities", quality in all spheres, including accompaniment by tutors in suitable centers. There is an obstacle that stands in the way of quality; the student needs to have a set of prior knowledge as to how to study, how to study in groups, about communication codes and technology, in addition to organizational routines and habits that are supposed to be developed by the primary school. If that school sets priority on the students acquisition of subject content alone, instead of getting the student to learn how to learn, then the student emanating from such a situation may well lack basic conditions. It is not by chance that the literature has tested and evaluated many alternatives (FIUZA; CASTELLÁ SARRIERA, 2013; HART, 2012; SIMPSON, 2012).

The analysis undertaken here also offers some lessons:1) a program must be contiually evaluated to correct its direction and minimize losses; 2) evaluation results need to transform in action; 3 ) nothing can be simply reduced to the injection of additional money. That is necessary but not suffient on its own for a program to achieve its purpose. One fundamental issue is to identify where, within the field of education, the money allocated goes. Anyone who has mastery of such knowledge is entitled to throw the first stone, but let it be a stone used for continuing to build. 


\section{Formação de professores qualificados: enxugando gelo?}

\section{Resumo}

A necessidade por professores para atuarem na educação básica brasileira, com a devida qualificação, ainda é alta. Procurando contribuir para a solução do problema, encontramos o Sistema Universidade Aberta do Brasil (UAB). Este estudo, quantitativo/descritivo, debruçou-se sobre dados oriundos do Sistema UAB - números de cursos, vagas, matrículas e formados, entre 2006 a junho de 2015. Verificou-se que a maioria das vagas disponibilizadas, 68,3\%, foram direcionadas à formação de professores, destas, especificamente $67,5 \%$ para formação inicial e 32,4\% para complementar. A taxa de matrícula orbitou os $86 \%$, enquanto que a de formados, foi cerca de $61 \%$. Com base nos números foi possivel concluir que o Sistema UAB procurou alcançar seu objetivo principal como política pública indutora da formação dos professores para a educação básica. Porém, conjectura-se que problemas ligados à carreira docente desestimulem os alunos a ingressarem e finalizarem os cursos, debilitando o potencial de atuação do Sistema.

Palavras-chave: Politica educacional. Formação de professores. Sistema Universidade Aberta do Brasil.

\section{Formación de profesores cualificados: ¿acción inútil?}

\section{Resumen}

La educación básica brasileña todavía carece de maestros calificados. El Sistema Universitario Abierto de Brasil (UAB) es una rama de una politica educativa pública diseñada para abordar este problema. Este artículo cuantitativo / descriptivo analiza las estadísticas del Sistema UAB (2006 a junio de 2015), especificamente en lo que respecta a vacantes, inscripción y número de alumnos que se gradúan. Se encontró que el 68,3\% de todas las vacantes se asignaron a cursos de formación de profesores, y en ese ámbito el 67,5\% correspondía a titulaciones de docentes de educación básica y el 32,4\% a cursos complementarios. El porcentaje de matrícula fue de alrededor del $86 \%$, mientras que la proporción de estudiantes que se graduaron fue de alrededor del 61\%. El análisis de las cifras sugiere que el Sistema UAB buscó alcanzar su objetivo principal, como una politica pública que induce la formación docente para el personal docente brasileño de educación básica. Sin embargo, se conjetura que los problemas relacionados con la profesión docente en si desalientan a los estudiantes de unirse y de finalizar sus cursos, debilitando así el potencial desempeño del Sistema UAB.

Palabras clave: Política educativa. Formación de profesores. Sistema Universidad Abierta de Brasil (UAB). 


\section{References}

ALMEIDA, M. P.; COSTA, M. L. F. Políticas públicas para o ensino superior a distância e a legislação educacional vigente. In: COSTA, M. L. F. (Org.). Introdução à educação a distância. Maringá: Eduem, 2009. p. 11-22.

ALVES, T.; SILVA, R. M. Estratificação das oportunidades educacionais o Brasil: contextos e desafios para a oferta de ensino em condições de qualidade para todos. Educação e Sociedade, v. 34, n. 124, p. 851-79, jul./set. 2013. https://doi.org/10.1590/S0101-73302013000300011

BARRETTO, E. S. S. Políticas de formação docente para a educação básica no Brasil: embates contemporâneos. Revista Brasileira de Educação, v. 20, n. 62, p. 679-701, jul./set. 2015. https://doi.org/10.1590/S1413-24782015206207

BRASIL. Decreto ${ }^{\circ}$ 5.800. de 8 de junho de 2006. Dispões sobre o Sistema Universidade Aberta do Brasil - UAB. Diário Oficial da União, 9 jun. 2006

. Lei $\mathrm{N}^{\circ}$ 9.394, de 20 de dezembro de1996. Estabelece as diretrizes e bases da educação nacional. Diário Oficial da União, 23 dez. 1996.

. Lei $\mathrm{N}^{\mathrm{o}} 10.172$, de 09 de janeiro de 2001. Aprova o Plano Nacional de Educação e dá outras providências. Diário Oficial da União, 10 jan. 2001.

FIUZA, P. J.; CASTELLÁ SARRIERA, J. Motivos para adesão e permanência discente na educação superior a distância. Psicologia: Ciência e Profissão, v. 33, n. 4, p. 884-901, 2013. https://doi.org/10.1590/S1414-98932013000400009.

GATTI, B. A. Formação inicial de professores para a educação básica: pesquisas e políticas educacionais. Estudos em Avaliação Educacional, v. 25, n. 57, p. 24-54, jan./abr. 2014. https://doi.org/10.18222/eae255720142823.

GOMES, C. A. Ensino superior a distância: lições de três experiências. In: Universidade do Terceiro Milênio. Plano Orientador da UENF. Campos dos Goytacazes, 1994. V. 3, p. 58-67.

A legislação que trata da EAD. In: LITTO, F. M.;

FORMIGA, M. C. M. (Orgs.). Educação a distância: o estado da arte. São Paulo: Pearson Education do Brasil, 2009. p. 21-7.

HART, C. Factors associated with student persistence in an online program of study: a review of literature. Journal of Interactive Online Learning, v. 11, n. 1, p. 19-42, 2012. 
INSTITUTO BRASILEIRO DE GEOGRAFIA E ESTATÍSTICA - IBGE. Projeção da população por sexo e idade: Brasil 2000-2060. Rio de Janeiro, 2013. Available from: $<$ http://www.ibge.gov.br/home/presidencia/noticias/imprensa/ppts /00000014425608112013563329137649.pdf >. Access: 2016 Dec. 10.

INSTITUTO NACIONAL DE ESTUDOS E PESQUISAS EDUCACIONAIS ANÍSIO TEIXEIRA - INEP. Sinopse estatística da educação básica de 2016. Brasília, DF, 2017. Available from: <http://download.inep.gov.br/ informacoes_estatisticas/sinopses_estatisticas/sinopses_educacao_basica/ sinopse_estatistica_educacao_basica_2016.zip>. Access: 2017 June 13.

LIRA, L. A. R.; LIMA, B. F. Z. Desafios da gestão de políticas públicas educacionais para formação de professores no âmbito do Sistema Universidade Aberta do Brasil. Em Rede Revista de Educação a Distância, v. 1, n. 1, p. 138-151, 2014.

NEDER, M. L. C. Educação a Distância e sua contribuição na mudança de paradigmas educacionais na formação de professores. In: BRASIL. Ministério da Educação. Desafios da educação a distância na formação de professores. Brasília, DF, 2006. p. 79-85.

ORGANISATION FOR ECONOMIC CO-OPERATION AND DEVELOPMENT - OECD. Purchasing power parities (PPP). Paris, 2017. Available from: $<$ https:// data.oecd.org/conversion/purchasing-power-parities-ppp.htm>. Access: 2017 Apr. 7.

PALAZZO, J.; GOMES, C. A. Teaching career's attraction and rejection factors: analysis of students and graduates perceptions in teacher education programs. Ensaio: Avaliação e Políticas Públicas em Educação, v. 25, n. 94, p. 90-113, jan./mar., 2017. https://doi.org/10.1590/s0104-40362017000100004.

PEIXOTO, M. C. L. Plano Nacional de Educação 2011-2020: desafios para a educação superior. In: CUNHA, C; SOUSA, J. V.; SILVA, M. A. (Orgs.). Universidade e educação básica: políticas e articulações possíveis. Brasília, DF: Liber, 2012. p. 67-91.

SIMPSON, O. Supporting students for success in online and distance education. New York: Routledge, 2012.

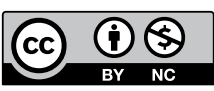

\section{Author information}

Bruno Teles Nunes: Doutorando do Programa de Pós-Graduação Stricto Sensu em Educação da Universidade Católica de Brasília (UCB). Contato: brunonunes@ymail.com. 